\title{
Penile Cancer pT1a TNM Finding v7
}

National Cancer Institute

\section{Source}

National Cancer Institute. Penile Cancer pT 1a TNM Finding v7. NCI Thesaurus. Code C89171.

Penile cancer with tumor invading subepithelial connective tissue without lymph vascular invasion and is not poorly differentiated (i.e., grade 3-4). (from AJCC 7th Ed.) 